\title{
Article \\ The Effect of Green Banking Practices on Banks' Environmental Performance and Green Financing: An Empirical Study
}

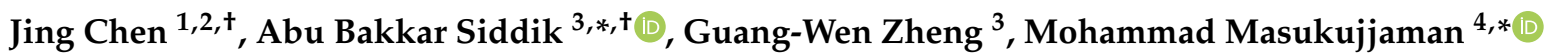 \\ and Sodikov Bekhzod ${ }^{3}$
}

check for updates

Citation: Chen, J.; Siddik, A.B.; Zheng, G.-W.; Masukujjaman, M.; Bekhzod, S. The Effect of Green Banking Practices on Banks' Environmental Performance and Green Financing: An Empirical Study. Energies 2022, 15, 1292. https:// doi.org/10.3390/en15041292

Academic Editor: Bahareh Oryani

Received: 28 December 2021

Accepted: 8 February 2022

Published: 10 February 2022

Publisher's Note: MDPI stays neutral with regard to jurisdictional claims in published maps and institutional affiliations.

Copyright: (C) 2022 by the authors. Licensee MDPI, Basel, Switzerland. This article is an open access article distributed under the terms and conditions of the Creative Commons Attribution (CC BY) license (https:// creativecommons.org/licenses/by/ $4.0 /)$.
1 School of Economics and Finance, Xi'an Jiaotong University, Xi'an 710061, China; xiyoucj@xupt.edu.cn

2 College of Economics and Management, Xi'an University of Posts and Telecommunications, Xi'an 710121, China

3 School of Economics and Management, Shaanxi University of Science and Technology (SUST), Weiyang District, Xi'an 710021, China; zhengguangwen@sust.edu.cn (G.-W.Z.); sssabv525@gmail.com (S.B.)

4 Department of Business Administration, Northern University Bangladesh, Banani C/A, Dhaka 1213, Bangladesh

* Correspondence: 1s190309@sust.edu.cn (A.B.S.); masukujjaman@nub.ac.bd (M.M.); Tel.: +86-156-8601-2117 (A.B.S.)

+ These authors contributed equally to this work.

\begin{abstract}
Every sector of the global economy is faced with environmental problems and their resulting consequences to their day-to-day operations. Due to the rising threat of global climate change, the green banking (GB) concept has been given significant attention in recent green finance literature Therefore, the main purpose of this study was to identify the impact of GB practices on banks' environmental performance and sources of green financing of private commercial banks (PCBs) in Bangladesh. Using a survey method, the primary data were obtained from a cross-sectional sample of 322 banking employees of PCBs in Bangladesh. In order to identify the key relationships existing between the study variables, structural equation modelling (SEM) approach was employed. The empirical findings indicated that banks' employees, daily-operations, and policy-related GB practices have significant positive effects on green financing, contrary to banks' customer-related GB practice, which was not statistically significant. Additionally, banks' green project financing exhibited a strong and positive influence on banks' environmental performance. Moreover, banks' daily operation and policy-related practices of GB were observed to have significant impacts on banks' environmental performances, in contrast to banks' employee and customer-related GB practices. Therefore, major policy implications and directions for future research in the concerned area are discussed.
\end{abstract}

Keywords: green banking practices; banks environmental performance; green financing; SEM; Bangladesh

\section{Introduction}

In a bid to enhance the economy and maximize wealth, humans continue to engage in activities that are detrimental to the environment. As a result, the world is faced with the challenges of climate change, such as floods and heat waves [1]. Concern for environmentrelated issues is increasing globally and, recently, among enterprises and institutions, leading to the development of various means of evaluating it. Consequently, countries have been assessed and classed according to their environmental performance ranking, where leading countries are awarded the 'Champion of the Earth Award' based on their adopted environmental measures [2]. Additionally, financial institutions are given the 'Golden Peacock Climate Management Award', while the 'Global Green Economy Index' and many other evaluation indexes are utilized to rank the global economies. Climate change remains one of the biggest problems facing both developed and developing countries in the world [3]. As most developing countries are in the transition period for economic 
and social development, they are, on the one hand, very vulnerable to climate change and, on the other hand, dependent on global climate finance to support climate protection and mitigation programs. However, many developing nations, such as Bangladesh, are struggling to reap this benefit due to their lack of effective institutions with project design and planning expertise $[1,3]$.

Bangladesh is considered one of the world's top emerging nations, with an immense investment and economic growth potential to be a dominant player in the 21st century [4]. However, the country is faced with the threats of climate change and its associated environmental implications. For instance, Bangladesh is considered one of the most susceptible nations in the world to the impact of climate changes such as the rise in global sea level, which has affected the natural ecosystem and expanded the economic deprivation of the population [5]. As a result, it has adopted numerous policies to reduce the risks and adverse environmental effects of climate change [6]. Some of the major strategies undertaken to prevent the degradation of the environment include the introduction of green banking and financing, in line with the global standard and the promotion of sustainable growth [1]. Green finance is a holistic concept whose key component is green banking [2]. Green Banking (GB) refers to banking activities that emphasize economic, social and ecological factors to protect the climate and natural resources $[7,8]$. Green banking requires investments in environmental products and services to combat climate change and protect the ecosystem. In a country like Bangladesh, GB is considered an important aspect of sustainable economic growth, as stated by Haque and Murtaz [9]. Therefore, it can also be said that GB plays an essential part in the global efforts to resolve climate change problems and achieve sustainable development goals (SDGs).

In recent years, the role of the banking community in environmental conservation and sustainability has been enormously highlighted within international forums such as the Paris Agreement, with the G20 group significantly considering the topic in their plans [2]. Therefore, GB is a broad term for principles and regulations that make banks economically, environmentally and socially sustainable [10]. The purpose is to enhance the effectiveness and efficiency of banking processes and the utilization of IT and physical infrastructure with zero or minimal ecological consequences. Furthermore, green- and environment-related policies are particularly important to emerging economies, given these economies' high susceptibility to climate change and global warming. Among other countries, Bangladesh is considered one of the first countries to pronounce the adoption of GB-related practices, having done so in 2011, to achieve sustainable economic development [11]. Bangladesh Bank (BB), the central bank and operator of the banking sector in Bangladesh, has been at the forefront of implementing green financing through GB development, which is pivotal to the progress and transition to a green economy towards the achievement of SDGs. GB is an important antecedent to the establishment of an effective green economy [5], which serves as an avenue for economic development in emerging markets and a medium to secure sustainability via low energy consumption and pollution $[12,13]$.

Additionally, various studies have recently been conducted in the area of GB, globally $[2,3,11,14-21]$. However, these studies are mainly focused on GB activities and its development in the context of Bangladesh [15,22,23]; green banking adoption [16,24,25]; GB performance and environmental sustainability $[19,21,22,26]$; and green finance $[1,5,27]$. Besides these, a couple of studies have been conducted to measure the impact of GB practices on banks' environmental performance in Pakistan [16], Nepal [28], India [18] and Sri Lanka [29]. In the context of Bangladesh, few studies have been conducted which examine the relationship between GB practices, green banking performance and banks' environmental performance $[15,19,21,22]$. However, there exist limited studies in the direction of GB practices' impact on banks' environmental performance and the sources of green financing based on the primary data in the context of PCBs in Bangladesh.

As such, this study endeavors to fill the previously established research gap in these ways: First, this study identifies various GB practices, including banks' employee-, operations-, customer- and policy-related practices in the context of PCBs, some of the 
significant contributors of green growth and green financing in Bangladesh $[1,5,30]$. Second, the study shows the impact of GB practices on banks' environmental performance based on bankers' perceptions. Third, the present study also analyzes the effect of these practices on the sources of green financing of PCBs based on primary data. Therefore, the main purpose of the study is to identify the impact of GB practices on banks' environmental performance and the sources of green financing in the context of PCBs in Bangladesh. In achieving the aforementioned objectives, the central research question of this study is as follows: What are the impacts of GB practices on banks' environmental performances (BEP) and the sources of green financing (SGF) in the context of PCBs in Bangladesh?

This study contributes to the existing literature, especially on GB, green finance and banks' environmental performance, in the following ways: First, the current study explores the research gap by analyzing the various GB practices theoretically and empirically based on bankers' knowledge of Bangladesh's banking sector. Second, the study measures the effect of GB practices on banks' environmental performance based on the structural equation modeling (SEM), as previous studies have mainly used descriptive statistics and multiple regression analysis to validate the relationships between study variables $[14,18,28,29]$. Third, this is a pioneering study that analyzes the relationship between various GB practices and the banks' sources of green financing based on the primary data obtained from bank's employees. To the best of the researcher's knowledge, no study has examined this issue globally, including in developing countries, such as Bangladesh, to date. Hence, we concentrate on bankers of PCBs who have strong understandings of GB activities, green finance and banks' internal environmental management in the context of Bangladesh.

The rest of the paper is structured accordingly: Section 2 discusses the relevant literature on GB, GB in Bangladesh, GB practices and banks' environmental performance, GB practices and green financing and hypotheses development. Section 3 introduces the research methods, which include study instruments, sample and data collection and methods of analysis. Section 4 presents the results, followed by discussions thereof in Section 5. Lastly, the major policy implications for GB growth and banks' mitigation of environmental effects through green financing are discussed, subsequent to the presentation of study limitations and future directions. The list of abbreviations and terminologies used in the study are presented in Table 1.

Table 1. List of abbreviations and terminologies used in the paper.

\begin{tabular}{|c|c|c|c|}
\hline Abbreviation & Explanation & Abbreviation & Explanation \\
\hline SDGs & sustainable development goals & $\mathrm{BB}$ & Bangladesh Bank \\
\hline GB & green banking & EFA & exploratory factor analysis \\
\hline SGF & sources of green financing & CFA & confirmatory factor analysis \\
\hline WHO & World Health Organization & SRMR & standardized root-mean residual \\
\hline CRF & Climate Risk Fund & AGFI & adjusted goodness of fit index \\
\hline BERP & banks' employee-related practices & $\mathrm{CA}$ & Cronbach's alpha \\
\hline BORP & banks' operation-related practices & AVE & average variance extracted \\
\hline BCRP & banks' customer-related practices & CR & composite reliability \\
\hline BPRP & banks' policy-related practices & GFI & goodness-of-fit index \\
\hline BEP & banks' environmental performance & AGFI & adjusted goodness-of-fit index \\
\hline SEM & structural equation modeling & SRW & standardized regression weight \\
\hline PCBs & private commercial banks & CFI & comparative fit index \\
\hline SCBs & state-owned commercial banks & NFI & normed fit index \\
\hline DFIs & development financial institutions & NNFI & non-normed fit index \\
\hline FCBs & foreign owned commercial banks & TLI & Tucker-Lewis index \\
\hline RMSEA & root-m & are error of a & tion \\
\hline
\end{tabular}

\section{Literature Review and Hypotheses Development}

Legitimacy theory emphasizes the significance of social consent in promoting a company's long-term viability [31]. It is widely believed that the phenomenon of corporations making voluntary social and environmental disclosures is explained by legitimacy the- 
ory [32]. Following the premise of legitimacy theory, businesses strive to gain, retain or restore their legitimacy through the use of social and environmental reporting practices [32]. According to Suchman [33], the study defines legitimacy as a generalized perception or assumption that Bangladeshi banks' actions are appropriate within the norms established by the regulator, Bangladesh Bank, in order to achieve organizational sustainability through the implementation of various activities, such as corporate social responsibility, green banking, and green finance, as it aids organizations in achieving the country's long-term development $[1,34]$. As a result, businesses must select activities that are acceptable and consistent with societal views, values, and conventions. Therefore, an extensive literature review on GB, green financing, and environmental performance is discussed further, as can be seen in Table A1 (see Appendix A).

\subsection{Green Banking}

Green banking is an evolving concept with an important role in the cross-cutting areas of environmental policy, financial institution operations and socio-economic growth [15]. The idea was first implemented in 1980 by the Dutch bank named 'Triodos Bank' [35]. Additionally, the bank developed a "Green Fund" for environmental projects and subsequently served as a reference to other banks pursuing green banking policies in $1990[5,15,35,36]$. Consequently, this has become a hot topic in the current banking sector, with a growing interest as sustainable practices against the external stress faced by banks [5,37]. As a responsible member of society, banks are mindful of environmental changes and play an important role in promoting and complementing public initiatives towards meaningful carbon reduction over the entire world via the implementation of green banking or sustainable banking practices [26].

\subsection{Green Banking in Bangladesh}

The BB is the world's first central bank with a strong vision of promoting GB activities to protect the environment from unusual weather conditions, increasing greenhouse gas and decreasing air quality [26]. In order to safeguard the environment, BB has specifically provided various guidelines for the activities of green banking. Bangladesh Bank published GB guidelines in 2011, which instructed banks to adopt and enforce comprehensive GB policy guidelines in three stages. In the first stage, banks need to develop an environmental policy, incorporate it into domestic operations and credit strategies and form a distinct GB unit. In addition, banks were also required to set up top-level regulatory bodies to revise, manage and assign budgets for green financing, environmental risk funds and internal capacity building [11]. In stage two, banking institutions were asked to develop industry-wide specific investment strategies for banking customers while being mindful of clients' environmental sensitivities, building green branches, incorporating environmental concerns in structured credit risk requirements, designing an environmental risk management guidebook for project assessment and reporting their green banking activities externally $[11,38,39]$. In the last stage, banking institutions were expected to develop new creative products and consistently publish verifiable GB activities records $[11,38]$.

\subsection{Green Banking Practices and Banks' Sources of Green Financing}

Green finance can be defined as a modern financial event that blends social and economic gains with environmental improvement [40]. Similarly, green finance represents a new growth of and engine for sustainable economic development, with social responsibility and environmental protection at its core [12]. Thus, green finance is aimed at harmonizing monetary improvement, environmental stability, ecological security and achievement of the country's sustainable economic development [41]. In addition, banks' overall internal carbon footprint and external carbon production can be minimized via the green financing of GB activities [1]. Furthermore, Haque and Murtaz [9] indicated that GB is one of the factors influencing the improvement of sustainable economic growth in emerging economies, while Zhang et al. [42] also noted that green finance, as a part of GB, is considered an 
important monetary tool for the sustainable economic growth of any country. Such banks mainly provide loans for various green financing projects, such as waste (solid and liquid) management, green establishment, green brick manufacturing (fire-burnt and non-fire block), industrial safety and security, clean energy, energy consumption, green tourism and alternative energy $[1,5,6,15,23]$.

More recently, Zheng et al. [1] studied the role of PCBs in the development of green finance in Bangladesh and identified the four major sources of green financing, based on banker's perceptions. The sources include investment in waste management, green establishment, green brick manufacturing recycling and recyclable product, all of which are instrumental to the environmental improvement by banks and the sustainable economic development of the country. In another study, Rehman et al. [16] showed that a positive relationship exists between the GB practices (operations and policy-related practices) and bank's green projects. Moreover, GB practices in banks resulted in the improvement of banks' environmental performances via the reduction of the negative environmental impacts resulting from daily operations, such as cutting paper use and reducing energy consumption, fuel consumption and emissions [29]. Banks also exert a positive effect on the environment by promoting proper GB activities in banks, such as the enhancement of environmental training and staff awareness, development of green buildings, provision of loans for green projects and the use of solar and wind energy $[1,5,43]$. Therefore, it can be said that the GB activities are essential for the improvement of banks' green financing and environmental performance towards attaining sustainable economic development in a country. Based on the aforementioned argument, the following research hypotheses are proposed:

Hypothesis 1 (H1). Banks' employee-related practices of GB significantly influence the sources of green financing.

Hypothesis 2 (H2). Banks' daily operation-related practices of GB significantly affect the sources of green financing.

Hypothesis 3 (H3). Banks' customer-related practices of GB significantly influence the sources of green financing.

Hypothesis 4 (H4). Banks' policy-related practices of GB significantly impact the sources of green financing.

Hypothesis 5 (H5). Banks' sources of green financing significantly influence the environmental performance of the bank.

\subsection{Green Banking Practices and Banks' Environmental Performance}

Green banking practices are not only promoted at the company level, but also at policy level, via green project funding, in order to ensure environmental sustainability (Rehman et al., 2021). Banks, being one of the key funding sources for many industries and companies, are expose to tremendous liability and responsibility, as they could indirectly contribute to environmental contamination if they fail to exercise strict environmental protection measures on industries and enterprises before they are financed [5,29]. On the one hand, banking institutions have also been criticized for being one of the major factors directly and indirectly affecting global climate change, resulting in the introduction of the green banking approach in the last decade to reduce the adverse impact of banks on the healthy environment [16]. On the other hand, banks are generally regarded as eco-friendly in terms of carbon emissions and environmental degradations, as they represent a key component of the economy and are closely linked to society [29]. Therefore, banks should be constructive in obliging industries to invest in climate protection and the use of suitable technology and management structures for mandated investment [38]. This helps banks to contribute to the improvement of the overall climate, quality of life, the performance of the material and energy usage, service quality and goods, despite environmental conservation not being their primary objective. 
Miah et al. [21] studied the factors influencing the environmental performance of the banking sector in Bangladesh using multiple regression analysis based on secondary information. They observed that credit-rating scores had a positive effect on banks' environmental performance, in contrast to bank's longevity in service. The study also reported that highly profitable banks are more concerned with environmental issues. More recently, Rehman et al. [16] studied the association between GB practices and their impact on banks' environmental performances, based on socially responsible investment (SRI) theory. The findings indicated that there is a strong positive relationship among policy-related practices, daily operations practices and green investments of GB in Pakistan. Additionally, the study also highlighted that the effect of green initiatives on policy decisions and investments in green infrastructure has become more prominent in fostering a green climate. Similarly, Shaumya and Arulrajah [29] studied the impact of GB practices impact on banks' environmental performance in Sri lanka. The study found that GB practices had a positive and significant effect on banks' environmental performance.

Moreover, Kala [18] identified the various green initiatives included by banking institutions into their practices to improve banks' environmental performance. GB practices include the environmental training of employees, energy-efficient practices, green financing, green projects and green policy. The study further showed that GB practices (environmental training of employees, energy-efficient practices, green policy and overall green projects) positively affected banks' environmental performance in city of Coimbatore, India. Similarly, Risal and Joshi [28] studied the impact of GB practices on banks' environmental performance in Nepal using multiple regression analysis. The study concluded that environmental training, banks' green policy and energy-efficient equipment significantly influenced the environmental performance of banks, contrary to the customer-related practices' (green financing and green projects), the effects of which were statistically insignificant. Hence, any organization's environmental performance can be measured by a number of metrics, including low environmental emissions, pollution control, waste reduction and recycling [44]. The environmental issues of banks, on the other hand, are primarily expressed in their initiatives, e.g., green finance, paperless banking, solar panel construction, recycling activities, maximum daily light usage, reduced use of gas and petroleum, investment in ecofriendly projects and marketing, climate risk-fund budgeting and the environmental risk assessment of projects [21]. In another study by Jha and Bhome [45], it was identified that the major GB strategies, which support the achievement of sustainable economic development in a country, include online banking, use of green checking accounts, saving paper, green loans for home improvement, green policy, green credit cards, use of solar energy and green products and services [5,23]. Therefore, it can be concluded that GB represents a means by which banks can reduce emissions and protect their environment in a bid to boost their environmental efficiency, and, consequently, raise their reputation as good corporate citizens towards the achievement of sustainable economic development in a region. Given the above-mentioned discussion, the following research hypotheses are stated:

Hypothesis 6 (H6). Banks' employee-related practices of GB significantly influence banks' environmental performance.

Hypothesis 7 (H7). Banks daily operation-related practices of GB significantly affect banks' environmental performance.

Hypothesis 8 (H8). Banks' customer-related practices of GB significantly influence banks' environmental performance.

Hypothesis 9 (H9). Banks' policy-related practices of GB significantly impact banks' environmental performance. 


\section{Materials and Methods}

This was exploratory research based on empirical data, as can be shown in Figure 1. The study utilized primary data from a survey of employees of the selected private commercial banks (PCBs) to identify the relationship between the GB practices, sources of green financing, and banks' environmental performance. Therefore, materials and methods are discussed further.

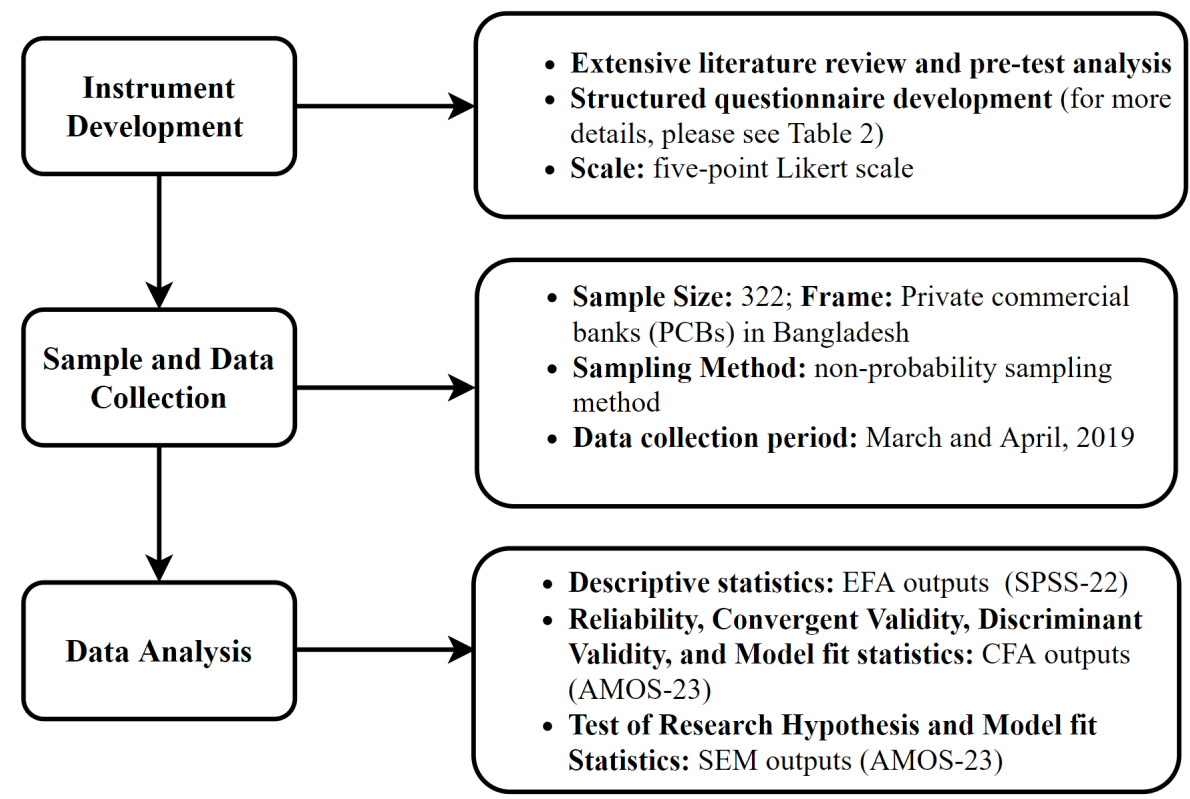

Figure 1. Flowchart of research materials and methods (source: authors' illustration).

\subsection{Instruments Development}

Table 2 shows the research questionnaire items that were used in the analysis to develop the research model, based on GB-related studies. The research questionnaire consisted of four parts, demographic information, GB practices, green financing and banks' environmental performance. The demographic part sought basic information about respondents, such as of age, gender, educational qualifications, job responsibilities and working experiences. The initial measurement items of BERP, BORP, BCRP and BPRP were formulated based on the related studies of refs. [16,28,29]. Furthermore, three items were developed from past studies $[1,5]$ to measure the sources of green financing. Similarly, four items were extracted to measure bank's environmental performances [18,28,29]. Moreover, the initial 22-item survey was pretested, initially, on 35 randomly selected bankers from seven commercial banks in Bangladesh. After conducting the EFA with the pilot sample respondents, three measurement items (GF4, GF5 and GF6) were deleted due to factor loading being less than 0.5. Finally, a structured questionnaire consisting of 19 measurement items was employed, with a five-point Likert scale, where one denoted 'strongly disagree' and five indicated 'strongly agree'. 
Table 2. Questionnaire Items.

\begin{tabular}{|c|c|c|c|}
\hline Variables & Items & Descriptions & Sources \\
\hline \multirow{3}{*}{ Banks' employee-related practices } & BERP1 & $\begin{array}{l}\text { Provision of environment-related training and } \\
\text { education }\end{array}$ & \multirow{3}{*}[28,29]{} \\
\hline & BERP2 & Sustainable performance evaluation system & \\
\hline & BERP3 & Green reward facilities & \\
\hline \multirow{3}{*}{ Banks' operation-related practices } & BORP1 & Reduction of paper usages & \multirow{3}{*}[16,29]{} \\
\hline & BORP2 & $\begin{array}{l}\text { Introduction of energy-efficient equipments, } \\
\text { such as ATMs and online banking. }\end{array}$ & \\
\hline & BORP3 & Provision of eco-friendly banking services & \\
\hline \multirow{3}{*}{ Banks' customer-related practices } & BCRP1 & Provision of loan for ecofriendly projects & \multirow{3}{*}{ [29] } \\
\hline & BCRP2 & $\begin{array}{l}\text { Provision of online banking services (i.e., online } \\
\text { bills payment, acceptance of remote deposit and } \\
\text { provision of e-statements) }\end{array}$ & \\
\hline & BCRP3 & Assessment of clients' environmental risks & \\
\hline \multirow{3}{*}{ Banks' policy-related practices } & BPRP1 & Establishment of more green branches & \multirow{3}{*}[16,29]{} \\
\hline & BPRP2 & Implementation of a green policy & \\
\hline & BPRP3 & $\begin{array}{c}\text { Promotion of green partnership among the } \\
\text { suppliers and investors }\end{array}$ & \\
\hline \multirow{6}{*}{ Green financing } & GF1 & $\begin{array}{l}\text { Increase in the amount invested on ecofriendly } \\
\text { projects }\end{array}$ & \multirow{6}{*}[1,5]{} \\
\hline & GF2 & $\begin{array}{l}\text { Investment of more resources on recycling and } \\
\text { recyclable products }\end{array}$ & \\
\hline & GF3 & $\begin{array}{l}\text { Increase in investment on waste management } \\
\text { and green brick manufacturing }\end{array}$ & \\
\hline & GF4 & $\begin{array}{l}\text { Increase in the amount invested on energy } \\
\text { efficiency projects * }\end{array}$ & \\
\hline & GF5 & $\begin{array}{l}\text { Increase in the amount invested on green } \\
\text { industry developemnt * }\end{array}$ & \\
\hline & GF6 & $\begin{array}{l}\text { Increase in the amount invested on green } \\
\text { marketing and others * }\end{array}$ & \\
\hline \multirow{4}{*}{ Banks environmental performance } & BEP1 & $\begin{array}{l}\text { Reduction of energy consumptions from banking } \\
\text { activities }\end{array}$ & \multirow{4}{*}[18,28,29]{} \\
\hline & BEP2 & $\begin{array}{l}\text { Minimization of carbon emissions from banking } \\
\text { activities }\end{array}$ & \\
\hline & BEP3 & $\begin{array}{l}\text { Improving banks' compliance with } \\
\text { environmental standards }\end{array}$ & \\
\hline & BEP4 & $\begin{array}{l}\text { Provision of training on environmental } \\
\text { protection and energy savings to the staffs }\end{array}$ & \\
\hline
\end{tabular}

Note: * Item has been deleted from the final analysis.

\subsection{Sample and Data Collection}

Approximately 57 banks, including state-owned commercial banks (SCBs), private commercial banks (PCBs) and foreign-owned commercial banks (FCBs), operate in Bangladesh, under the supervision of the Bangladesh Bank (BB), the central bank of Bangladesh. Of all the banking institutions, PCBs were the main contributor to the development of GB in Bangladesh, as they are the largest funder of the practice $[1,23,30]$. Additionally, they contribute significantly to the growth and development of the green economy in Bangladesh. Consequently, PCBs were particularly selected for this study. The main purpose of the study is to determine the major GB practices in the context of PCBs, and then examine their effects 
on the sources of green financing and banks' environmental performances. To fulfill the stated research objectives, primary data were utilized in this study. Using a non-probability sampling method, primary data were obtained mainly from the employees of the selected PCBs. A total of 354 structured questionnaires were delivered for the collection of data, between March and April 2019, of which 322 were recovered, indicating a retrieval rate of $90.96 \%$. Finally, the study employed a five-point Likert scale, ranging from 1one (strongly disagree) to five (strongly agree), to measure the response of the employees.

\subsection{Data Analysis Strategy}

Three main methodological approaches used in this analysis to analyze the obtained primary data were IBM SPSS (version 22.0) and AMOS (version 23.0). The main analytical techniques include exploratory factor analysis (EFA), confirmatory factor analysis (CFA) and structural equation modeling (SEM). EFA is a data-driven strategy that is commonly used as a technique for identifying relationship among variables [46]. Conducting an EFA entails screening and processing data for analysis, extracting eigenvalues, calculating the number of factors in a solution, rotating the factors to produce a more interpretable solution and offering an interpretation for the solution [46,47]. Therefore, the EFA approach was applied in this study to screen and process the data for further analysis, as previous studies ignored, thus facing a validity crisis in identifying relationships between their study variables [14,18]. According to Gerbing and Anderson [48], in the output of the CFA, values of the standardized coefficients, critical ratios and other model fit indices are assessed to determine the measurement model of a study.

On the other hand, conducting a SEM analysis includes selecting the model, gathering and screening acceptable data, estimating the model's parameters, analyzing the model's fit to the data, interpreting the model's parameters and evaluating the plausibility of competing models [46]. To test the proposed research model (Figure 2), the study employed a two-step statistical approach, as recommended by Hair et al. [47-49]. In the first step, the CFA measurement model was examined. In the second step, the SEM approach was used to identify the structural relationships among the latent constructs. To measure the reliability of the study variables, the Cronbach's alpha (CA) and composite reliability (CR) values were employed [50]. In addition, the study's convergent validity was calculated by the average variance extracted (AVE) and standardized factor loading values [47]. In order to identify the discriminant validity, the study employed both the Fornell-Larcker [51] and HeterotraitMonotrait ratio (HTMT) [52] approaches. Finally, the measurement and structural model fit were measured using the various model fit indices, viz. chi-square/degrees of freedom $\left(\mathrm{X}^{2} / \mathrm{df}\right)$, goodness-of-fit index (GFI), standard root-mean-square residual (SRMR), rootmean-square error of approximation (RMSEA), comparative fit index (CFI), normed fit index (NFI), incremental fit index (IFI) and Tucker-Lewis index (TLI), in line with past studies [49,53-55]. To this end, Figure 2 shows the hypothesized conceptual research model of the study. 


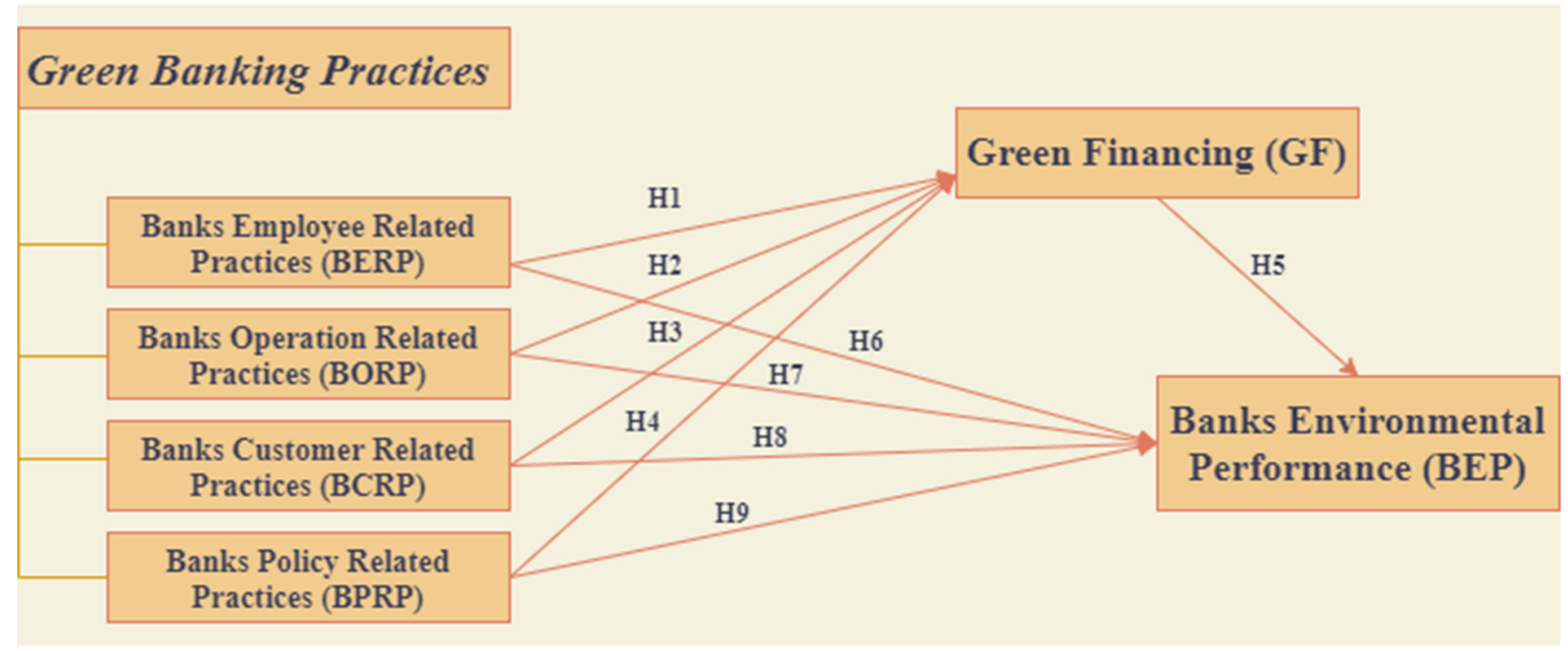

Figure 2. Conceptual framework of the study.

\section{Empirical Findings}

The empirical finding section covers the demographic profile of the respondents, descriptive statistics, reliability and validity of constructs, followed by the measurement model, structural equation modeling, and the outcomes of the research hypothesis.

\subsection{Respondent's Profile}

Table 3 shows the demographic information of the respondents. Findings of the study indicated that $68.01 \%$ of the respondents were male, while $31.99 \%$ were female. Among the respondents, $17.08 \%$ were aged 18 to 25 years; $45.03 \%$, 26 to 35 years; $31.99 \%$, 36 to 45 years; and $5.90 \%, 46$ years and above. In terms of educational level, $61 \%$ had postgraduate qualifications, $23.91 \%$ had completed an undergraduate degree, almost $10 \%$ had other degrees, and $4.66 \%$ had PhD degrees. Therefore, it could be inferred that a majority of the respondents were well educated. With respect to the job positions held by the survey respondents, $23.29 \%$ were principal officers; $25.47 \%$, junior officers; $18.32 \%$, officers; and $14.60 \%$ were senior principal officers, followed by banking trainees and managers, accounting for $13.04 \%$ and $5.27 \%$, respectively. The empirical findings revealed that $55.90 \%$ of the respondents had worked for $1-4$ years; $32.60 \%$, less than a year; and $11.50 \%$ more than 4 years.

\subsection{Descriptive Statistics (EFA)}

Table 4 describes the findings of the EFA using the principal component Analysis (PCA). The EFA was performed to analyze its suitability to explain the six perceived dimensions of the eigenvalue of each factor produced, which included four aspects of GB practice, green financing and the environmental performances of the sample banks. By measuring the correlations matrix, the suitability of data for factor analysis was assessed, and adequate correlation was observed between measurements. The number of factors to be maintained was calculated using the eigenvalue parameters [56]. According to Kaiser, the obtained Kaiser-Meyer-Oklin value of 0.895 is perceived to be appropriate. The significance level of Bartlett's sphericity test attained a value of $p<0.000$, confirming the correlation matrix's goodness of fit. The communalities of the 19 measures ranged from 0.693 to 0.886 and the results indicated coherence within the six-dimensional model, which represented a total variance of 63.301 percent. Subsequent to the EFA, three items (GF4, GF5 and GF6) were deleted, due to poor loading of their factors. The coefficient alpha of reliability was determined for each factor to verify the internal accuracy of each dimension, 
and the alpha values were observed to range between 0.735 and 0.819 confirming the reliability and validity of the developed instrument [57].

Table 3. Demographic information of the respondents.

\begin{tabular}{|c|c|c|c|}
\hline Variable & Items & Frequency (N) & Percent (\%) \\
\hline \multirow{2}{*}{ Gender } & male & 219 & 68.01 \\
\hline & female & 103 & 31.99 \\
\hline \multirow{4}{*}{ Age } & 18-25 years & 55 & 17.08 \\
\hline & 26-35 years & 145 & 45.03 \\
\hline & $36-45$ years & 103 & 31.99 \\
\hline & 46 years and above & 19 & 05.90 \\
\hline \multirow{4}{*}{$\begin{array}{l}\text { Educational } \\
\text { qualification }\end{array}$} & undergraduate & 77 & 23.91 \\
\hline & postgraduate & 198 & 61.49 \\
\hline & $\mathrm{PhD}$ & 15 & 04.66 \\
\hline & others & 32 & 09.94 \\
\hline \multirow{6}{*}{ Job position } & officers & 59 & 18.32 \\
\hline & principal officers & 75 & 23.29 \\
\hline & senior principal officers & 47 & 14.60 \\
\hline & junior officers & 82 & 25.47 \\
\hline & banking trainee & 42 & 13.04 \\
\hline & manager & 17 & 05.27 \\
\hline \multirow{3}{*}{ Working experience } & less than 1 year & 105 & 32.60 \\
\hline & 1 to 4 years & 180 & 55.90 \\
\hline & above 4 years & 37 & 11.50 \\
\hline
\end{tabular}

Source: The authors' calculations.

Table 4. Model estimates and factor extraction outcomes of the EFA.

\begin{tabular}{|c|c|c|c|c|c|c|c|}
\hline \multicolumn{8}{|c|}{ Factor Loadings } \\
\hline Variables & Items & 1 & 2 & 3 & 4 & 5 & 6 \\
\hline \multirow{3}{*}{$\begin{array}{c}\text { Banks' } \\
\text { employee-related } \\
\text { practices }\end{array}$} & BERP1 & 0.862 & & & & & \\
\hline & BERP2 & 0.864 & & & & & \\
\hline & BERP3 & 0.870 & & & & & \\
\hline \multirow{3}{*}{$\begin{array}{c}\text { Banks' }^{\prime} \\
\text { operation-related } \\
\text { practices }\end{array}$} & BORP1 & & 0.862 & & & & \\
\hline & BORP2 & & 0.791 & & & & \\
\hline & BORP3 & & 0.776 & & & & \\
\hline \multirow{3}{*}{$\begin{array}{c}\text { Banks' }^{\prime} \\
\text { customer-related } \\
\text { practices }\end{array}$} & BCRP1 & & & 0.855 & & & \\
\hline & BCRP2 & & & 0.830 & & & \\
\hline & BCRP3 & & & 0.750 & & & \\
\hline \multirow{3}{*}{$\begin{array}{c}\text { Banks' policy-related } \\
\text { practices }\end{array}$} & BPRP1 & & & & 0.843 & & \\
\hline & BPRP2 & & & & 0.867 & & \\
\hline & BPRP3 & & & & 0.761 & & \\
\hline
\end{tabular}


Table 4. Cont.

\begin{tabular}{|c|c|c|c|c|c|c|c|}
\hline \multicolumn{8}{|c|}{ Factor Loadings } \\
\hline Variables & Items & 1 & 2 & 3 & 4 & 5 & 6 \\
\hline \multirow{3}{*}{ Green financing } & GF1 & & & & & 0.868 & \\
\hline & GF2 & & & & & 0.886 & \\
\hline & GF3 & & & & & 0.818 & \\
\hline \multirow{4}{*}{$\begin{array}{l}\text { Banks' environmental } \\
\text { performance }\end{array}$} & BEP1 & & & & & & 0.693 \\
\hline & BEP2 & & & & & & 0.744 \\
\hline & BEP3 & & & & & & 0.823 \\
\hline & BEP4 & & & & & & 0.801 \\
\hline Eigenvalue & & 2.257 & 1.970 & 1.981 & 2.041 & 2.207 & 2.353 \\
\hline
\end{tabular}

Source: The authors' calculations

\subsection{Discriminant Validity}

To examine the discriminant validity, the discrepancy between the AVE square root value and the correlation coefficient among the factors were employed $[47,51,58]$. The AVE square root values were in the range of 0.673 to 0.790 , which exceeded their interconstruct squared correlations, as presented in Table 5 .

Table 5. Discriminant validity (Fornel-Larker method).

\begin{tabular}{cccccccccc}
\hline & BERP & BORP & BCRP & BPRP & GF & BEP & AVE & $\begin{array}{c}\text { CR } \\
\text { Cronbach's } \\
\text { Alpha }\end{array}$ \\
\hline BERP & 0.790 & & & & & & 0.624 & 0.833 & 0.760 \\
\hline BORP & 0.429 & 0.673 & & & & 0.453 & 0.709 & 0.735 \\
\hline BCRP & 0.388 & 0.587 & 0.708 & & & 0.501 & 0.750 & 0.742 \\
\hline BPRP & 0.410 & 0.438 & 0.401 & 0.732 & & 0.535 & 0.773 & 0.765 \\
\hline GF & 0.465 & 0.518 & 0.529 & 0.473 & 0.751 & & 0.560 & 0.795 & 0.819 \\
\hline BEP & 0.486 & 0.648 & 0.699 & 0.579 & 0.650 & 0.751 & 0.423 & 0.745 & 0.760 \\
\hline
\end{tabular}

Note: The AVE root values are diagonal values in italic form and interconstruct squared correlations are the off-diagonal values.

For robustness, this study also calculated the HTMT value due to its supremacy over Fornell-Larcker in various situations [52]. The results of the HTMT values are shown in the Table 6 , and the values are less than $0.85 / 0.90$, indicating that there is no discriminant validity problem [52]. As a result of the findings, it is possible to conclude that the presence of discriminant validity among the variables studied is verified and acceptable. $[47,51,52,58]$

Table 6. Discriminant validity using Heterotrait-Monotrait Ratio (HTMT).

\begin{tabular}{ccccccc}
\hline Variables & BERP & BORP & BCRP & BPRP & GF & BEP \\
\hline BERP & & & & & \\
\hline BORP & 0.581 & & & & \\
\hline BCRP & 0.645 & 0.774 & & & \\
\hline BPRP & 0.652 & 0.679 & 0.659 & & & \\
\hline GF & 0.653 & 0.653 & 0.728 & 0.683 & \\
\hline BEP & 0.677 & 0.769 & 0.837 & 0.754 & 0.743 & \\
\hline Source: Authors' calculation & & & & &
\end{tabular}

Source: Authors' calculation 


\subsection{Measurement Model}

The output of the CFA, values of the standardized coefficients, critical ratios and other model fit indices were assessed to assess the measurement model of the study, according to Gerbing and Anderson [48]. Thereafter, the values of the CR, CA, AVE and other fit statistics were used to evaluate the convergent validity of the model. Table 7 presents the findings of the measurement model, in which all of the standardized coefficients, excluding items BORP2 (0.55) for banks' operation-related practices, and BEP1, for banks environmental performance construct, exceeded 0.6 [59]. According to Hair et al., (2014), high factor loading is an initial predictor of overall convergent validity, as it converges on a common point, i.e., a latent structure. The AVE values of the BERP, BCRP, BPRP and GF constructs exceeded the standard value of 0.5 [47,59], except for the BORP and BEP constructs, as presented in Table 5. On the other hand, the CR values ranged from 0.709 to 0.833 , surpassing the recommended value of $0.6[47,59]$. Consequently, the convergent validity of the measurements was considered adequate and appropriate, since the $C R$ values exceeded 0.60 and the AVE values were lower than 0.50 [60,61]. Similarly, the Cronbach's alphas of the six factors ranged from 0.735 to 0.819 , which exceeded the acceptable limit of 0.7. Likewise, the alpha values of the six variables range from 0.735 to 0.819 , which fell above the acceptable limit of 0.7 [47]. Therefore, based on results of the AVE, CA and CR, it could be established that the validity and internal reliability of the variables with their respective measurement constructs were sufficient and acceptable [51].

Table 7. Model Estimates and CFA.

\begin{tabular}{|c|c|c|c|c|c|c|c|}
\hline Variable & Const & & Item No & SRW & CR & $p$-Value & $\operatorname{CA}(\alpha)$ \\
\hline \multirow{3}{*}{ Banks' employee-related practices } & BERP & $\rightarrow$ & BERP1 & 0.781 & 14.347 & $* * *$ & \multirow{3}{*}{0.760} \\
\hline & BERP & $\rightarrow$ & BERP3 & 0.826 & * & & \\
\hline & BERP & $\rightarrow$ & BERP2 & 0.762 & 13.993 & $* * *$ & \\
\hline \multirow{3}{*}{ Banks' operation-related practices } & BORP & $\rightarrow$ & BORP3 & 0.777 & * & & \multirow{3}{*}{0.735} \\
\hline & BORP & $\rightarrow$ & BORP2 & 0.551 & 7.943 & $* * *$ & \\
\hline & BORP & $\rightarrow$ & BORP1 & 0.672 & 10.978 & $* * *$ & \\
\hline \multirow{3}{*}{ Banks' customer-related practices } & BCRP & $\rightarrow$ & BCRP3 & 0.638 & 10.514 & $* * *$ & \multirow{3}{*}{0.742} \\
\hline & BCRP & $\rightarrow$ & BCRP2 & 0.722 & 11.829 & $* * *$ & \\
\hline & BCRP & $\rightarrow$ & BCRP1 & 0.758 & * & & \\
\hline \multirow{3}{*}{ Banks' policy-related practices } & BPRP & $\rightarrow$ & BPRP3 & 0.613 & 10.536 & $* * *$ & \multirow{3}{*}{0.765} \\
\hline & BPRP & $\rightarrow$ & BPRP2 & 0.829 & * & & \\
\hline & BPRP & $\rightarrow$ & BPRP1 & 0.737 & 12.673 & $* * *$ & \\
\hline \multirow{3}{*}{ Green financing } & GF & $\rightarrow$ & GF3 & 0.750 & 12.052 & $* * *$ & \multirow{3}{*}{0.819} \\
\hline & GF & $\rightarrow$ & GF2 & 0.781 & * & & \\
\hline & GF & $\rightarrow$ & GF1 & 0.720 & 14.514 & $* * *$ & \\
\hline \multirow{4}{*}{ Banks environmental performance } & $\mathrm{BEP}$ & $\rightarrow$ & BEP3 & 0.676 & 10.337 & $* * *$ & \multirow{4}{*}{0.760} \\
\hline & $\mathrm{BEP}$ & $\rightarrow$ & BEP2 & 0.667 & * & & \\
\hline & $\mathrm{BEP}$ & $\rightarrow$ & BEP1 & 0.593 & 9.287 & $* * *$ & \\
\hline & BEP & $\rightarrow$ & BEP4 & 0.662 & 10.146 & $* * *$ & \\
\hline
\end{tabular}

Note: SRW—-standardized regression weight; CR—critical ratio; CA—Cronbach's alpha. * Unstandardized regression weights anticipated as $1 .{ }^{* *}$ Significant level at $p<0.05$.

Table 8 depicts that the empirical findings of the measurement model fit indices fell within acceptable standards [53]. The measurement model fit indices included $\chi^{2} / \mathrm{df}=2.186$; $\mathrm{GFI}=0.920 ; \mathrm{SRMR}=0.027 ; \mathrm{RMSEA}=0.061 ; \mathrm{TLI}=0.927 ; \mathrm{IFI}=0.943 ; \mathrm{CFI}=0.943 ; \mathrm{NFI}=0.900 ;$ 
$p$-value $=0.000$. Therefore, based on the output of the various model fit indices, it could be concluded that the overall model was adequate and satisfactory.

Table 8. Measurement and structural model fit indices.

\begin{tabular}{cccc}
\hline Model Fit Indices & Measurement Model & Structural Model & Cut-Off Criteria \\
\hline$\chi^{2} / \mathrm{df}$ & 2.186 & 2.324 & $<0.05$ \\
\hline$p$-value & 0.000 & 0.000 & Significant at $p<0.001$ \\
\hline GFI & 0.920 & 0.914 & $>0.900$ \\
\hline SRMR & 0.027 & 0.029 & $<0.08$ \\
\hline RMSEA & 0.061 & 0.064 & $<0.08$ \\
\hline CFI & 0.943 & 0.934 & $>0.900$ \\
\hline NFI & 0.900 & 0.891 & $>0.900$ \\
\hline IFI & 0.943 & 0.935 & $>0.900$ \\
\hline TLI & 0.927 & 0.918 & $>0.900$ \\
\hline
\end{tabular}

Note. $\chi^{2} / \mathrm{df}$-chi-square/degrees of freedom; GFI—goodness-of-fit index; SRMR—standard root-mean-square residual; RMSEA—root-mean-square error of approximation; CFI—comparative fit index; NFI—normed fit index; IFI-incremental fit index; TLI-Tucker-Lewis index.

\subsection{Structural Model}

Figure 3 depicts the structural model of the study and shows the impact of the relationship among the latent variables and constructs. It can be concluded that the GB practices (BERP, BORP, BCRP and BPRP) have positive effects on green financing and banks' environmental performance. In addition to that, model fit indices were also employed in identifying the suitability of the structural model. Table 8 indicates that the structural model fit indices lay within acceptable standard limits (Hu and Bentler, 1999). The structural model fit indices included $\chi^{2} / \mathrm{df}=2.324 ; \mathrm{GFI}=0.914 ;$ SRMR $=0.029 ;$ RMSEA $=0.064$; $\mathrm{TLI}=0.918 ; \mathrm{IFI}=0.935 ; \mathrm{CFI}=0.943 ; \mathrm{NFI}=0.891 ;$ and $p$-value $=0.000$. Therefore, based on the output of the different indices, it could be concluded that the overall structural model was acceptable and satisfactory.

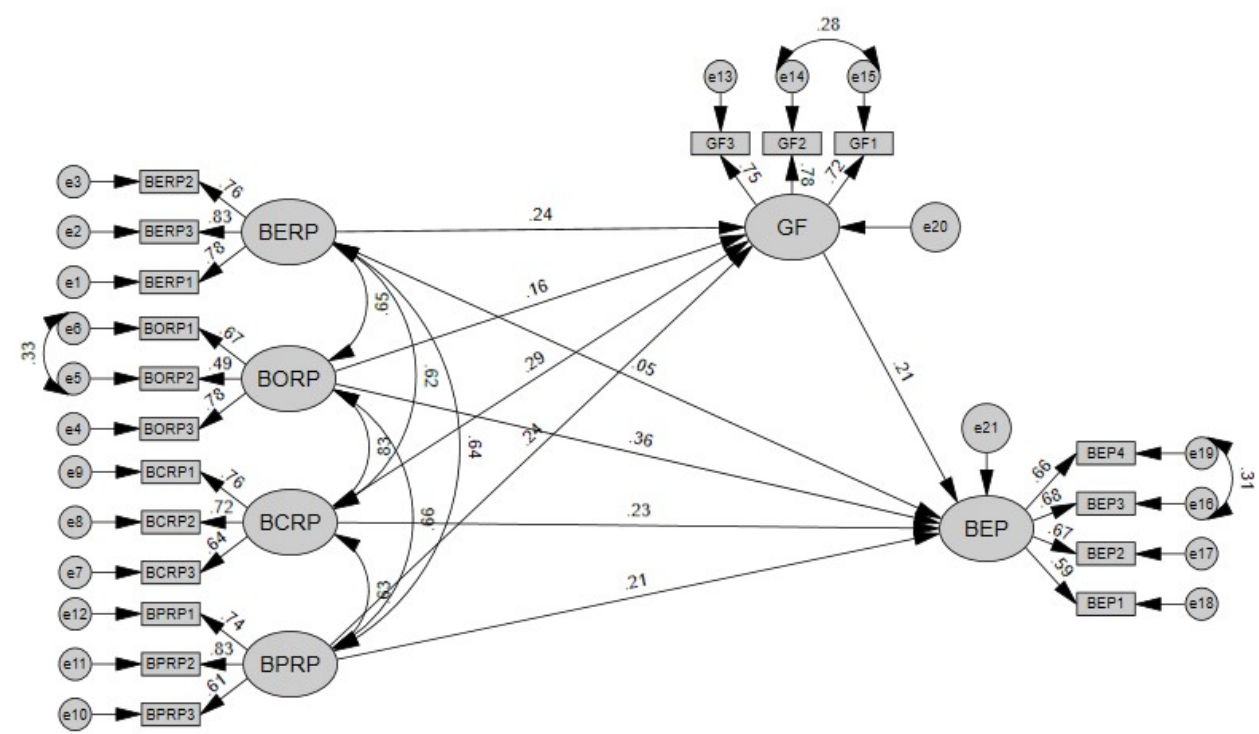

Figure 3. Structural model with standardized estimates. Note: BERP—banks' employee-related practices; BORP—banks' operation-related practices; $\mathrm{BCRP}$ —banks' customer-related practices; $\mathrm{BPRP}$ banks' policy-related practices; GF-green financing; $\mathrm{BEP}$-banks' environmental performance. 


\subsection{Test of Research Hypotheses}

Subsequent to the assessment of the overall model fit indices in the measurement model, a structural model was employed to test the research hypotheses in the second stage. Table 9 shows the output of the research hypotheses addressed in the study. The empirical findings indicated that banks' employee-related practices, banks' operation-related practices and banks' policy-related practices of GB have significant and positive effects on green financing $(\beta=0.275, p<0.01 ; \beta=0.318, p<0.05 ; \beta=0.252, p<0.01)$, which corroborate hypotheses H1, H2 and H4. On the other hand, banks' customer-related practices of GB were found to have a positive path coefficient but not a statistically significant effect on green financing $(\beta=0.170)$, indicating that $\mathrm{H} 3$ is not supported. Subsequently, the results indicated the significant effect of green financing on banks' environmental performances $(\beta=0.183, p<0.10)$, implying the validity of Hypothesis 5 .

Table 9. Test of Research Hypotheses.

\begin{tabular}{cccc}
\hline Hypotheses & Path & $\begin{array}{c}\text { Standardized } \\
\text { Estimate }\end{array}$ & Remark \\
\hline H1 & $\mathrm{BERP} \rightarrow \mathrm{GF}$ & $0.275^{* * *}$ & accepted \\
H2 & $\mathrm{BORP} \rightarrow \mathrm{GF}$ & $0.318^{* *}$ & accepted \\
H3 & $\mathrm{BCRP} \rightarrow \mathrm{GF}$ & 0.170 & not accepted \\
$\mathrm{H} 4$ & $\mathrm{BPRP} \rightarrow \mathrm{GF}$ & $0.252^{* * *}$ & accepted \\
$\mathrm{H} 5$ & $\mathrm{GF} \rightarrow \mathrm{BEP}$ & $0.183^{*}$ & accepted \\
$\mathrm{H} 6$ & $\mathrm{BERP} \rightarrow \mathrm{BEP}$ & 0.043 & not accepted \\
$\mathrm{H} 7$ & $\mathrm{BORP} \rightarrow \mathrm{BEP}$ & $0.335^{* *}$ & accepted \\
$\mathrm{H} 8$ & $\mathrm{BCRP} \rightarrow \mathrm{BEP}$ & 0.219 & not accepted \\
$\mathrm{H} 9$ & $\mathrm{BPRP} \rightarrow \mathrm{BEP}$ & $0.204^{* *}$ & accepted
\end{tabular}

Banks' operation-related practices and banks' policy-related practices of GB have significant impact on banks' environmental performance $(\beta=0.335, p<0.01 ; \beta=0.204$, $p<0.05)$, supporting hypotheses H7 and H9. In contrast, the impacts of banks' employee and customer-related practices of the GB had a positive path coefficient on banks' environmental performance $(\beta=0.043, \beta=0.219)$, but were however, observed to be statistically insignificant. Therefore, the findings indicated that $\mathrm{H} 6$ and $\mathrm{H} 8$ were unsupported.

\section{Discussions}

As exhibited in Figure 4, the empirical findings indicated that Hypothesis 1 is supported and that a significant relationship exists between banks' employee-related practices in GB and the sources of green financing by PCBs in Bangladesh. This result is consistent with the findings of Raihan [62] and Zheng et al. [1], which states that bankers' knowledge, beliefs and attitude towards GB practices have a positive influence on the various sources of green financing towards the achievement of sustainable economic development in Bangladesh. As a result, it can be concluded that GB practices (including employeerelated practices) play a crucial role in the development of sustainable financing of PCBs in Bangladesh.

Based on the results, Hypothesis 2, which maintains that banks' daily operation-related practices have positive impact on the sources of green financing by PCBs, is also validated. This finding is in agreement with past studies [1,16]. As stated, the green-related daily practices of banks, such as the provision of eco-friendly banking services and a reduction in paper consumption, have positively influenced the financing of banks' green projects. On the other hand, Hypotheses 3 is not validated, as no significant relationship exists between banks' customer-related practices and green projects financing. Therefore, this finding is in agreement with the study conducted by $[1,28,29]$, which indicates that banks' customerrelated practices such as the provision of online banking and assessment of customers' environmental risks, have not directly affected banks' green financing decisions. However, it can be observed that banks' customer-related activities are considered one of the GB 
practices, as it fails to comply with the decision of green projects financing by banking institutions, owing to its direct relation with customers.

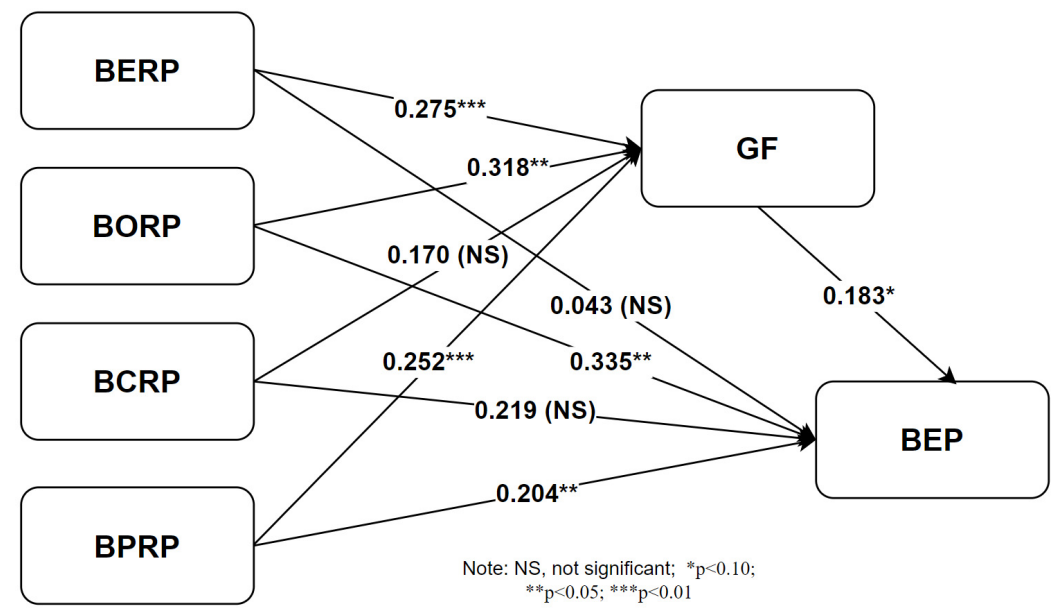

Figure 4. Estimated model.

The results indicate the acceptance of Hypothesis 4 and highlight a statistically significant relationship between banks' policy-related practices and the sources of green financing. Recently, a study conducted by Rehman et al. [16] identified the positive relationship existent between banks' policy-related practices and green projects' financing towards the adoption of GB in Pakistan; therefore, our findings are validated by the present study. Furthermore, the empirical result indicates the validity of Hypothesis 5 and confirms that the sources of green financing have a positive impact on the environmental performances of banks. This finding is in line with the study conducted by Kala et al. [18], which indicates that green projects' financing has a positive influence on the overall environmental performances of banks. Therefore, it can also be established that green finance has become a new growth accelerator, fostering green economic growth, with social responsibility and environmental concerns being its priorities. More surprisingly, the empirical evidence indicates the non-existence of a meaningful association between banks' employee-related practices and environmental performance, consequently invalidating Hypothesis 6 . This result is inconsistent with results obtained from other studies $[18,28,29]$, which highlight that employee-related GB practices, comprising the provision of environment-related training and education, sustainable performance evaluation systems and green reward facilities, have a positive impact on the environmental performances of banks. However, our findings may differ from previous studies due to a lack of GB knowledge and environmental training and education among bank employees. Therefore, it is recommended that banking authorities provide sufficient training to their employees to improve GB performance and reduce the adverse environmental impact on the society through the provision of green financing.

Since the output validates Hypothesis 7, the daily operation-related practices of GB have a positive impact on banks' environmental performances. Consequently, this finding is supported by previous studies [18,28,29]. As stated, GB daily operation-related practices, such as the provision of online banking and reduction in paper consumption, have directly contributed to the reduction of negative environmental impacts and improved banks' environmental performances. Moreover, based on these results, Hypothesis 8 is invalidated because no significant relationship exists between banks' customer-related practices and the environmental performances of PCBs in Bangladesh. Therefore, this result is consistent with previously conducted studies [28,29]. It has been discovered in the study that banks' customer-related practices have not directly influenced their environmental performances. Although banks' customer-related practices are regarded as one of the activities of GB, they do not contribute directly to their environmental performances due to its direct connection to customers. Finally, Hypothesis 9 is validated as indicated by its statistical significance. Banks' green policy-related practices have a positive impact on their environmental perfor- 
mances, and our findings are supported by past studies $[18,28,29]$. They opine that banks green policy-related practices, including the establishment of more green branches, the implementation of a green policy and the promotion of green partnership among suppliers and investors, positively affect banks' environmental performance. Therefore, it can be concluded that GB activities, such as employee, customer, policy and operation-related practices, have direct and indirect effects on the green project financing of banks and their environmental performances, owing to their contributions towards the achievement of sustainable development in the country.

\section{Conclusions}

The aim of the study was to identify the impact of GB practices on banks' environmental performance and the sources of green financing in the context of PCBs in Bangladesh. Primary data were obtained from bankers of PCBs in Bangladesh and were subsequently analyzed using factor analysis (EFA and CFA) techniques for the study validity, reliability and assessment of the model fit among the variables of the research model. The empirical findings suggested that the overall study model was accepted and deemed satisfactory, based on the output of various model fit indices. Afterwards, the SEM technique was employed to assess the research hypotheses. The empirical findings revealed that the BERP, BORP and BCRP of GB practices have significant positive effects on green financing, contrary to the BCRP of GB practice, which was not statistically significant. Additionally, banks' green project financing exhibited a strong and positive influence on banks' environmental performance. Moreover, BORP and BPRP of GB practices were observed to have significant impacts on banks' environmental performance, in contrast to the BERP and BCRP of GB practices. Therefore, major policy implications, limitations and directions for future research in the concerned area were discussed further.

The findings of the study provide valuable implications for academics, banking institutions, bankers, managers and government officials in Bangladesh through the promotion of green banking and provision of green funding to boost banks' environmental performances and, consequently, the country's sustainable economic development. This research helps academics to comprehend the effect of GB practices on the funding of green projects and the environmental performance of banks, while the output of the study also contributes to the GB literature. The main policy implications were subsequently explored: First, GB practices such as bank employees, daily-operation and green policy-related practices, were observed to positively affect the sources of green financing of PCBs in Bangladesh. Therefore, a proposal was made to maintain PCBs and provide employees with necessary environmental training programs to support green financing via the adoption of GB in their daily banking operations. Second, the results indicated that the customer-related practices of GB have not affected banks' sources of green financing. However, it could not be concluded that banks' customer-related activities are considered a GB practice, as they failed to comply with the decisions of green project financing by banking institutions, which are directly related to customers. Thus, the PCBs and government of Bangladesh should conduct various seminars, training and symposiums on the advantages of GB to increase the sensitivity of bank clients and the public towards green practices. Third, the daily operation and policy-related practices of GB had a positive influence on the environmental performances of banks. Therefore, the managers of PCBs are requested to incorporate daily operation and policy-related activities of GB in the banking system through the reduction of paper usage, provision of ecofriendly-banking practices such as ATMs and online banking, establishment of green branches and implementation of green policies to improve banks' environmental performance. Fourth, the effect of the employees and the customer-related activities of GB on the environmental performance of banks were observed to be statistically insignificant. This indicates that the employees and customers of banks lack the knowledge of GB concerning its reducing the negative environmental performance of the banking system. To bridge this knowledge gap among bank employees and customers, PCBs should be provided with environmental training and education to improve their 
environmental performances. Finally, the study indicated that the cooperation between the government, banking institutions and international organizations is required to adopt GB practices through green financing and determine how these practices influence banks' environmental performances, in general. In this respect, BB should play a dynamic role in the education, organization, promotion and monitoring of GB-related activities, to help in the attainment of a country's sustainable economic growth.

Similar to other studies, the present research also had some limitations. First, since employees of PCBs were incorporated in the study, the results can only be applied to a particular community. Therefore, the results of the present study could be strengthened by analyzing different stakeholders (e.g., customers and owners) among other banking institutions operated in Bangladesh, such as state-owned banks (SCBs), foreign-owned commercial banks (FCBs), Islamic banks (IBs) and non-bank financial institutions (NBFIs). Second, future research could extend the range of this study by examining the impact of green banking practices on the sustainable performance and profitability of banks through analysis of the mediating effects of green financing. Third, employees' knowledge of GB practices may differ between SCBs, IBs, FCBs and NBFIs. Therefore, this could be discussed by various companies in future research. Finally, in order to assess green finance and banks' environmental performance sources, rather than considering the views of customers and owners of sample banks, the analysis only took employee opinions on different GB practices into account.

Author Contributions: Conceptualization, A.B.S.; Data curation, J.C., A.B.S. and S.B.; Formal analysis, A.B.S. and M.M.; Investigation, M.M.; Methodology, A.B.S. and M.M.; Project administration, G.-W.Z.; Resources, J.C., G.-W.Z. and S.B.; Software, J.C. and A.B.S.; Supervision, G.-W.Z.; Visualization, M.M. and S.B.; Writing-original draft, J.C. and A.B.S.; Writing-review and editing, G.-W.Z. and M.M. All authors have read and agreed to the published version of the manuscript.

Funding: This study was funded by the Xi'an Social Science Planning Fund (Grant No. JX08).

Institutional Review Board Statement: Not applicable.

Informed Consent Statement: Oral consent was obtained from all individuals involved in this study.

Data Availability Statement: The data that support the findings of this study are available from the corresponding authors (A.B.S.) upon reasonable request.

Acknowledgments: The researchers would like to express their gratitude to the anonymous reviewers for their efforts to improve the quality of this paper.

Conflicts of Interest: The authors declare no conflict of interest.

\section{Appendix A}

Table A1. Summary of recent empirical studies.

\begin{tabular}{|c|c|c|c|c|}
\hline Source & Title of the Study & Methodology & Variables & Main Findings \\
\hline Zhang et al. [63] & $\begin{array}{c}\text { Do Green } \\
\text { Banking } \\
\text { Activities } \\
\text { Improve the } \\
\text { Banks' } \\
\text { Environmental } \\
\text { Performance? } \\
\text { The Mediating } \\
\text { Effect of } \\
\text { Green Financing }\end{array}$ & $\begin{array}{l}\text { data: primary; } \\
\text { sample: } 352 ; \\
\text { analysis: SEM } \\
\text { approach }\end{array}$ & $\begin{array}{l}\text { green banking } \\
\text { activities, green } \\
\text { financing, and } \\
\text { environmental } \\
\text { performance }\end{array}$ & $\begin{array}{l}\text { The findings indicated that green } \\
\text { banking activities exhibited a } \\
\text { significantly positive effect on banks' } \\
\text { environmental performance and sources } \\
\text { of green financing, and that the sources } \\
\text { of green financing significantly } \\
\text { influence banks' environmental } \\
\text { performances. In addition, the study } \\
\text { also found that green financing } \\
\text { mediated the association between green } \\
\text { banking activities and banks' } \\
\text { environmental performance. }\end{array}$ \\
\hline
\end{tabular}


Table A1. Cont.

\begin{tabular}{|c|c|c|c|c|}
\hline Source & Title of the Study & Methodology & Variables & Main Findings \\
\hline Rehman et al. [16] & $\begin{array}{l}\text { Adoption of } \\
\text { green banking } \\
\text { practices and } \\
\text { environmental } \\
\text { performance in } \\
\text { Pakistan: a } \\
\text { demonstration of } \\
\text { structural } \\
\text { equation } \\
\text { modelling }\end{array}$ & $\begin{array}{l}\text { data: primary; } \\
\text { sample: } 200 ; \\
\text { analysis: SEM } \\
\text { approach }\end{array}$ & $\begin{array}{l}\text { policy and } \\
\text { operations related } \\
\text { practices of GB, } \\
\text { and green } \\
\text { investment }\end{array}$ & $\begin{array}{l}\text { The empirical results revealed that } \\
\text { policy, daily operations and investments } \\
\text { significantly influence the adoption of } \\
\text { green banking practices. }\end{array}$ \\
\hline Zheng et al. [13] & $\begin{array}{l}\text { Factors Affecting } \\
\text { the Sustainability } \\
\text { Performance of } \\
\text { Financial } \\
\text { Institutions in } \\
\text { Bangladesh: The } \\
\text { Role of Green } \\
\text { Finance }\end{array}$ & $\begin{array}{c}\text { data: both } \\
\text { primary and } \\
\text { secondary; } \\
\text { sample: } 302 ; \\
\text { analysis: SEM } \\
\text { approach }\end{array}$ & $\begin{array}{c}\text { green finance } \\
\text { dimensions } \\
\text { (social, economic, } \\
\text { and } \\
\text { environmental) } \\
\text { and sustainability } \\
\text { performance }\end{array}$ & $\begin{array}{l}\text { The empirical findings showed that the } \\
\text { dimensions of green finance are related } \\
\text { to the economic, social and } \\
\text { environmental aspects of SDGs. In } \\
\text { addition, the empirical findings } \\
\text { revealed that the dimensions of green } \\
\text { finance-social, economic and } \\
\text { environmental-had a strong positive } \\
\text { effect on the sustainability performances } \\
\text { of banks. }\end{array}$ \\
\hline Khairunnessa et al. [15] & $\begin{array}{l}\text { A Review of the } \\
\text { Recent } \\
\text { Developments of } \\
\text { Green Banking in } \\
\text { Bangladesh }\end{array}$ & $\begin{array}{l}\text { data: secondary; } \\
\text { sample: banks } \\
\text { operated in } \\
\text { Bangladesh; } \\
\text { analysis: } \\
\text { descriptive } \\
\text { statistics, relative } \\
\text { percentage } \\
\text { changes, graphs, } \\
\text { and figure }\end{array}$ & not applicable & $\begin{array}{l}\text { The study indicated that the Central } \\
\text { Bank of Bangladesh played a major role } \\
\text { in greening the financial system of the } \\
\text { country by implementing various green } \\
\text { policies and regulatory measures. } \\
\text { Although Bangladesh is still far behind } \\
\text { the developed countries in terms of } \\
\text { environmental performance, the country } \\
\text { has made remarkable progress in } \\
\text { initiating and expanding green banking } \\
\text { practices, infrastructure development } \\
\text { and accelerating green growth in recent } \\
\text { years. }\end{array}$ \\
\hline Zheng et al. [1] & $\begin{array}{l}\text { Green Finance } \\
\text { Development in } \\
\text { Bangladesh: The } \\
\text { Role of Private } \\
\text { Commercial } \\
\text { Banks (PCBs) }\end{array}$ & $\begin{array}{c}\text { data: both } \\
\text { primary and } \\
\text { secondary; } \\
\text { sample: } 296 ; \\
\text { analysis: CFA 1st } \\
\text { and 2nd order }\end{array}$ & $\begin{array}{c}\text { green finance } \\
\text { dimensions } \\
\text { (social, economic, } \\
\text { and } \\
\text { environmental) } \\
\text { and sources of } \\
\text { green financing }\end{array}$ & $\begin{array}{l}\text { The findings of the study identified the } \\
\text { "economic dimension" as the most } \\
\text { significant dimension affecting the level } \\
\text { of bankers' perceptions of GF. } \\
\text { Additionally, bankers perceived the } \\
\text { "social and environmental dimensions" } \\
\text { as being the second and third most } \\
\text { crucial factors influencing GF, followed } \\
\text { by sources of green financing. }\end{array}$ \\
\hline Kala et al. [18] & $\begin{array}{l}\text { A Study on The } \\
\text { Impact of Green } \\
\text { Banking Practices } \\
\text { on Bank's } \\
\text { Environmental } \\
\text { Performance With } \\
\text { Special Reference } \\
\text { To Coimbatore } \\
\text { City }\end{array}$ & $\begin{array}{l}\text { data: primary; } \\
\text { sample: } 143 ; \\
\text { analysis: multiple } \\
\text { regression }\end{array}$ & $\begin{array}{l}\text { environmental } \\
\text { training, } \\
\text { energy-efficient } \\
\text { equipment, green } \\
\text { loan, green } \\
\text { project, green } \\
\text { policy, and } \\
\text { environmental } \\
\text { performance. }\end{array}$ & $\begin{array}{l}\text { The results of the study suggested that } \\
\text { environmental training, energy-efficient } \\
\text { practices and green projects had } \\
\text { significant impact on bank's } \\
\text { environmental performances. }\end{array}$ \\
\hline
\end{tabular}


Table A1. Cont.

\begin{tabular}{|c|c|c|c|c|}
\hline Source & Title of the Study & Methodology & Variables & Main Findings \\
\hline Bose et al. [22] & $\begin{array}{l}\text { Does Green } \\
\text { Banking } \\
\text { Performance Pay } \\
\text { Off? Evidence } \\
\text { from a Unique } \\
\text { Regulatory } \\
\text { Setting in } \\
\text { Bangladesh }\end{array}$ & $\begin{array}{l}\text { data: secondary; } \\
\text { sample: } 172 ; \\
\text { analysis: } \\
\text { difference-in- } \\
\text { differences (DiD) } \\
\text { and propensity } \\
\text { score matching } \\
\text { (PSM) }\end{array}$ & not applicable & $\begin{array}{l}\text { The findings of the study suggested that } \\
\text { green banking performance was } \\
\text { positively associated with a bank's } \\
\text { financial performance. Further analysis } \\
\text { showed that cost efficiency mainly } \\
\text { drives this relationship. However, } \\
\text { banks' political connections negatively } \\
\text { affected this relationship by } \\
\text { counterbalancing green banking's } \\
\text { non-financial benefits. }\end{array}$ \\
\hline Risal and Joshi [28] & $\begin{array}{l}\text { Measuring Green } \\
\text { Banking Practices } \\
\text { onvalley } \\
\text { Empirical } \\
\text { Evidence from } \\
\text { Kathmandu } \\
\text { valley }\end{array}$ & $\begin{array}{c}\text { data: primary; } \\
\text { sample: } 189 ; \\
\text { analysis: multiple } \\
\text { regression }\end{array}$ & $\begin{array}{l}\text { environmental } \\
\text { training, } \\
\text { energy-efficient } \\
\text { equipment, green } \\
\text { loan, green } \\
\text { project, green } \\
\text { policy, and } \\
\text { environmental } \\
\text { performance. }\end{array}$ & $\begin{array}{l}\text { The study concluded that } \\
\text { energy-efficient equipment and green } \\
\text { policy posed a significant impact on a } \\
\text { bank's environmental performance; } \\
\text { green loans and green projects did not. } \\
\text { Similarly, environmental training } \\
\text { contributed mildly to a bank's } \\
\text { environmental performance. }\end{array}$ \\
\hline Miah and Haque [21] & $\begin{array}{l}\text { Factors affecting } \\
\text { environmental } \\
\text { performance: } \\
\text { evidence from } \\
\text { banking sector in } \\
\text { Bangladesh }\end{array}$ & $\begin{array}{l}\text { data: secondary; } \\
\text { sample: } 31 \text { banks; } \\
\text { analysis: multiple } \\
\text { regression } \\
\text { analysis }\end{array}$ & $\begin{array}{l}\text { credit rating score, } \\
\text { total asset, net } \\
\text { profit, market } \\
\text { price per share, } \\
\text { bank age, and } \\
\text { environmental } \\
\text { performance } \\
\text { score }\end{array}$ & $\begin{array}{l}\text { The study found that a bank's credit } \\
\text { rating score was positively related to } \\
\text { environmental performance, whereas } \\
\text { premium in share price and bank's } \\
\text { longevity in service were negatively } \\
\text { associated with environmental } \\
\text { performance. }\end{array}$ \\
\hline $\begin{array}{l}\text { Shaumya and } \\
\text { Arulrajah [29] }\end{array}$ & $\begin{array}{l}\text { The Impact of } \\
\text { Green Banking } \\
\text { Practices on } \\
\text { Bank's } \\
\text { Environmental } \\
\text { Performance: } \\
\text { Evidence from Sri } \\
\text { Lanka }\end{array}$ & $\begin{array}{c}\text { data: primary; } \\
\text { sample: } 155 ; \\
\text { analysis: multiple } \\
\text { regression }\end{array}$ & $\begin{array}{l}\text { green banking } \\
\text { activities } \\
\text { (employee, policy, } \\
\text { operation, and } \\
\text { customer) and } \\
\text { environmental } \\
\text { performance }\end{array}$ & $\begin{array}{l}\text { The study found that green banking } \\
\text { practices had a positive and significant } \\
\text { impact on a bank's environmental } \\
\text { performance, overall, and it also found } \\
\text { that employee-related practice, daily } \\
\text { operation-related practice and a bank's } \\
\text { policy-related practice were found to } \\
\text { have a positive and significant impact } \\
\text { on a bank's environmental performance; } \\
\text { however, customer-related practice had } \\
\text { no significant impact on bank's } \\
\text { environmental performance. }\end{array}$ \\
\hline
\end{tabular}

Source: Authors' compilation from the recent literature.

\section{References}

1. Zheng, G.W.; Siddik, A.B.; Masukujjaman, M.; Fatema, N.; Alam, S.S. Green Finance Development in Bangladesh: The Role of Private Commercial Banks (PCBs). Sustainability 2021, 13, 795. [CrossRef]

2. Sarma, P.; Roy, A. A Scientometric Analysis of Literature on Green Banking (1995-March 2019). J. Sustain. Financ. Invest. 2020, 11, 1-20. [CrossRef]

3. Ngwenya, N.; Simatele, M.D. The Emergence of Green Bonds as an Integral Component of Climate Finance in South Africa. S. Afr. J. Sci. 2020, 116, 10-12. [CrossRef]

4. Nawaz, M.A.; Seshadri, U.; Kumar, P.; Aqdas, R.; Patwary, A.K.; Riaz, M. Nexus between Green Finance and Climate Change Mitigation in N-11 and BRICS Countries: Empirical Estimation through difference in Differences (DID) Approach. Environ. Sci. Pollut. Res. 2020, 28, 6504-6519. [CrossRef] [PubMed]

5. Akter, N.; Siddik, A.B.; Mondal, M.S.A. Sustainability Reporting on Green Financing: A Study of Listed Private Sustainability Reporting on Green Financing: A Study of Listed Private Commercial Banks in Bangladesh. J. Bus. Technol. 2018, XII, $14-27$.

6. Hossain, M. Green Finance in Bangladesh: Policies, Institutions, and Challenges. ADBI Work. Pap. Ser. 2018, 892, 1-24.

7. Chowdhury, T.U.; Datta, R.; Mohajan, H.K. Green Finance Is Essential for Economic Development and Sustainability. Int. J. Res. Commer. 2013, 3, 104-108. 
8. Rai, R.; Kharel, S.; Devkota, N.; Paudel, U.R. Customers Perception on Green Banking Practices: A Desk Review Customers Perception on Green Banking Practices: A Desk Review. J. Econ. Concerns 2019, 10, 83-95.

9. Haque, M.S.; Murtaz, M. Green Financing in Bangladesh. In Proceedings of the International Conference on Finance for Sustainable Growth and Development; Jahur, M.S., Uddin, S.M.S., Eds.; Department of Finance, Faculty of Business Administration, University of Chittagong: Chittagong, Bangladesh, 2018; pp. 82-89.

10. Srivastava, A. Green Banking: Support and Challenges. Int. Adv. Res. J. Sci. Eng. Technol. 2016, 3, 135-137. [CrossRef]

11. Bose, S.; Khan, H.; Rashid, A.; Islam, S. What Drives Green Banking Disclosure? An Institutional and Corporate Governance Perspective. Asia Pac. J. Manag. 2018, 35, 501-527. [CrossRef]

12. Liu, N.; Liu, C.; Xia, Y.; Ren, Y.; Liang, J. Examining the Coordination between Green Finance and Green Economy Aiming for Sustainable Development: A Case Study of China. Sustainability 2020, 12, 3717. [CrossRef]

13. Zheng, G.; Siddik, A.B.; Masukujjaman, M.; Fatema, N. Factors Affecting the Sustainability Performance of Financial Institutions in Bangladesh: The Role of Green Finance. Sustainability 2021, 13, 165. [CrossRef]

14. Malsha, K.P.P.H.G.N.; Anton Arulrajah, A.; Senthilnathan, S. Mediating Role of Employee Green Behaviour towards Sustainability Performance of Banks. J. Gov. Regul. 2020, 9, 92-102. [CrossRef]

15. Khairunnessa, F.; Vazquez-Brust, D.A.; Yakovleva, N. A Review of the Recent Developments of Green Banking in Bangladesh Sustainability 2021, 13, 1904. [CrossRef]

16. Rehman, A.; Ullah, I.; Afridi, F.-A.; Ullah, Z.; Zeeshan, M.; Hussain, A.; Rahman, H.U. Adoption of Green Banking Practices and Environmental Performance in Pakistan: A Demonstration of Structural Equation Modelling. Environ. Dev. Sustain. 2021, 23, 13200-13220. [CrossRef]

17. Qureshi, H.; Hussain, T. Green Banking Products: Challenges and Issues in Islamic and Traditional Banks of Pakistan. J. Account. Financ. Emerg. Econ. 2020, 6, 703-712.

18. Vidyakala, K. A Study on The Impact of Green Banking Practices on Bank's Environmental Performance With Special Reference To Coimbatore City. Afr. J. Bus. Econ. Res. 2020, 15, 1-6. [CrossRef]

19. Julia, T.; Kassim, S.; Julia, T. Exploring Green Banking Performance of Islamic Banks vs. Conventional Banks in Bangladesh Based on Maqasid Shariah framework. J. Islam. Mark. 2019, 11, 729-744. [CrossRef]

20. Sharmeen, K.; Hasan, R.; Miah, M.D. Underpinning the Benefits of Green Banking: A Comparative Study between Islamic and Conventional Banks in Bangladesh. Thunderbird Int. Bus. Rev. 2019, 61, 735-744. [CrossRef]

21. Miah, M.D.; Rahman, S.M.; Haque, M. Factors Affecting Environmental Performance: Evidence from Banking Sector in Bangladesh. Int. J. Financ. Serv. Manag. 2018, 9, 22-38. [CrossRef]

22. Bose, S.; Khan, H.Z.; Monem, R.M. Does Green Banking Performance Pay off? Evidence from a Unique Regulatory Setting in Bangladesh. Corp. Gov. Int. Rev. 2021, 29, 162-187. [CrossRef]

23. Hoque, N.; Mowla, M.M.; Uddin, M.S.; Mamun, A.; Uddin, M.R. Green Banking Practices in Bangladesh: A Critical Investigation. Int. J. Econ. Financ. 2019, 11, 58. [CrossRef]

24. Rifat, A.; Nisha, N.; Iqbal, M.; Suviitawat, A. The Role of Commercial Banks in Green Banking Adoption: A Bangladesh Perspective. Int. J. Green Econ. 2016, 10, 226-251. [CrossRef]

25. Tu, T.T.T.; Dung, N.T.P. Factors Affecting Green Banking Practices: Exploratory Factor Analysis on Vietnamese Banks. J. Econ. Dev. 2017, 24, 4-30. [CrossRef]

26. Zhixia, C.; Hossen, M.M.; Muzafary, S.S.; Begum, M. Green Banking for Environmental Sustainability-Present Status and Future Agenda: Experience from Bangladesh. Asian Econ. Financ. Rev. 2018, 8, 571-585. [CrossRef]

27. Raihan, M.Z.; Khan, M.S.U. Sustainable Finance-A Prerequisite for Growth \& Development of Banking Industry in Bangladesh In Proceedings of the Finance for Sustainable Growth and Development; Department of Finance, Faculty of Business Administration, University of Chittagong: Chittagong, Bangladesh, 2018; pp. 29-49.

28. Risal, N.; Joshi, S.K. Measuring Green Banking Practices on Bank's Environmental Performance: Empirical Evidence from Kathmandu Valley. J. Bus. Soc. Sci. 2018, 2, 44-56. [CrossRef]

29. Shaumya, S.; Arulrajah, A. The Impact of Green Banking Practices on Bank's Environmental Performance: Evidence from Sri Lanka. J. Financ. Bank Manag. 2017, 5, 77-90. [CrossRef]

30. Hossain, M. Green Finance in Bangladesh Barriers and Solutions. In Handbook of Green Finance, Sustainable Development; Springer: Singapore, 2019; pp. 1-26. ISBN 9789811087103.

31. Indriastuti, M.; Chariri, A. Social Responsibility Investment on Sustainable The Role of Green Investment and Corporate Social Responsibility Investment on Sustainable Performance. Cogent Bus. Manag. 2021, 8, 8. [CrossRef]

32. Mousa, G.; Hassan, N.T. Legitimacy Theory and Environmental Practices: Short Notes. Int. J. Bus. Stat. Anal. 2015, 2, 42-53.

33. Suchman, M.C. Managing Legitimacy: Strategic and Institutional Approaches. Acad. Manag. Rev. 1995, 20, 571-610. [CrossRef]

34. Weber, O.; Chowdury, R.K. Corporate Sustainability in Bangladeshi Banks: Proactive or Reactive Ethical Behavior? Sustainability 2020, 12, 7999. [CrossRef]

35. Yadav, R.; Pathak, G.S. Environmental Sustainability through Green Banking: A Study on Private and Public Sector Banks in India. OIDA Int. J. Sustain. Dev. 2013, 6, 37-48.

36. Islam, M.S.; Das, P.C. Green Banking Practices in Bangladesh. IOSR J. Bus. Manag. 2013, 8, 39-44. [CrossRef]

37. Lalon, R.M. Green Banking: Going Green. Int. J. Econ. Financ. Manag. Sci. 2015, 3, 34-42. [CrossRef] 
38. Masukujjaman, M.; Aktar, S. Green Banking in Bangladesh: A Commitment towards the Global Initiatives. J. Bus. Technol. 2014, 8, 17-40. [CrossRef]

39. Rahman, M.M.; Ahsan, M.A.; Hossain, M.M.; Hoq, M.R. Green Banking Prospects in Bangladesh. Asian Bus. Rev. 2015, 2, 59. [CrossRef]

40. Wang, Y.; Zhi, Q. The Role of Green Finance in Environmental Protection: Two Aspects of Market Mechanism and Policies. Energy Procedia 2016, 104, 311-316. [CrossRef]

41. Zhou, X.; Tang, X.; Zhang, R. Impact of Green Finance on Economic Development and Environmental Quality: A Study Based on Provincial Panel Data from China. Environ. Sci. Pollut. Res. 2020, 27, 19915-19932. [CrossRef] [PubMed]

42. Zhang, D.; Zhang, Z.; Managi, S. A Bibliometric Analysis on Green Finance: Current Status, Development, and Future Directions. Financ. Res. Lett. 2019, 29, 425-430. [CrossRef]

43. Shaumya, K.; Arulrajah, A.A. Measuring Green Banking Practices: Evidence from Sri Lanka. In Proceedings of the 13th International Conference on Business Management 2016, Colombo, Sri Lanka, 8 December 2016; pp. 1000-1023.

44. Lober, D.J. Evaluating the Environmental Performance of Corporations. J. Manag. Issues 1996, 8, 184.

45. Jha, D.N.; Bhome, S. A Study of Green Banking Trends in India. Int. Mon. Ref. J. Res. Manag. Technol. $2013,2,127-132$.

46. Ockey, G.J. Exploratory Factor Analysis and Structural Equation Modeling. In The Companion to Language Assessment; John Wiley \& Sons, Ltd.: Hoboken, NJ, USA, 2013; pp. 1224-1244. ISBN 9781118411360.

47. Hair, J.F.; Black, W.C.; Babin, B.J.; Anderson, R.E. Multivariate Data Analysis, 4th ed.; Prentice Hall: Upper Saddle River, NJ, USA, 2010.

48. Gerbing, D.W.; Anderson, J.C. An Updated Paradigm for Scale Development Incorporating Unidimensionality and Its Assessment. J. Mark. Res. 1988, 25, 186-192. [CrossRef]

49. Bagozzi, R.P.; Yi, Y. On the Evaluation of Structural Equation Models. J. Acad. Mark. Sci. 1988, 16, 74-94. [CrossRef]

50. Nunnally, J.; Bernstein, I. Psychometric Theory, 3rd ed.; McGraw-Hill: New York, NY, USA, 1994.

51. Fornell, C.; Larcker, D.F. Evaluating Structural Equation Models with Unobservable Variables and Measurement Error. J. Mark. Res. 1981, 18, 39. [CrossRef]

52. Henseler, J.; Ringle, C.M.; Sarstedt, M. A New Criterion for Assessing Discriminant Validity in Variance-Based Structural Equation Modeling. J. Acad. Mark. Sci. 2015, 43, 115-135. [CrossRef]

53. Hu, L.T.; Bentler, P.M. Cutoff Criteria for Fit Indexes in Covariance Structure Analysis: Conventional Criteria versus New Alternatives. Struct. Equ. Model. 1999, 6, 1-55. [CrossRef]

54. Bollen, K.A. A New Incremental Fit Index for General Structural Equation Models. Sociol. Methods Res. 1989, 17, 303-316. [CrossRef]

55. Browne, M.W.; Cudeck, R. Alternative Ways of Assessing Model Fit. Sociol. Methods Res. 1992, 21, 230-258. [CrossRef]

56. Cattell, R.B. The Scree Test for the Number of Factors. Multivariate Behav. Res. 1966, 1, 245-276. [CrossRef]

57. Nunnally, J.C. Psychometric Theory, 2nd ed.; McGraw-Hill: New York, NY, USA, 1979.

58. Chin, W. The Partial Least Squares Approach to SEM Chapter. Mod. Methods Bus. Res. 1998, 295, $295-336$.

59. Awang, Z. Research Methodology and Data Analysis, 2nd ed.; Universiti Teknologi Mara, UiTM Press: Selangor, Malaysia, 2014.

60. Lam, L.W. Impact of Competitiveness on Salespeople's Commitment and Performance. J. Bus. Res. 2012, 65, 1328-1334. [CrossRef]

61. Huang, C.-C.; Wang, Y.-M.; Wu, T.-W.; Wang, P.-A. An Empirical Analysis of the Antecedents and Performance Consequences of Using the Moodle Platform. Int. J. Inf. Educ. Technol. 2013, 3, 217-221. [CrossRef]

62. Raihan, M.Z. Sutainable Finance for Growth and Development of Banking Industry in Bangladesh: An Equity Perspective. MIST J. Sci. Technol. 2019, 7, 41-51.

63. Zhang, X.; Wang, Z.; Zhong, X.; Yang, S.; Siddik, A.B. Do Green Banking Activities Improve the Banks' Environmental Performance? The Mediating Effect of Green Financing. Sustainability 2022, 14, 989. [CrossRef] 